\title{
LYMPHOGRANULOMA VENEREUM (LYMPHOGRANULOMA INGUINALE) *
}

\author{
BY
}

\author{
T. LYALL
}

\section{Birkenhead and Seamen's Dispensary, Liverpool}

So far as can be discovered, British medical literature has produced only one article in which the primary sore of lymphogranuloma venereum has been illustrated (Hanschell, 1938). Two cases, one male and one female, with primary lesions have been described, but not illustrated (Fowler and Walker, 1947). It was felt that it would be of interest, therefore, to describe a male patient, seen in Liverpool in 1954, with a photograph of the lesion which was probably the herpetiform primary.

Of 130 cases of lymphogranuloma venereum seen over 19 years by Hanschell (1938), only four showed primary sores, and, although this disease is diagnosed in some twenty cases yearly in the Seamen's Clinic where the present case was seen, the primary lesion does not appear to have been noted previously.

Stokes, Beerman, and Ingraham (1944) describe the sore as a herpetiform vesicle with a whitishgrey base, and the incubation period is given as from a few days to 5 weeks. It is mentioned that the lesion may frequently be missed by both patient and doctor because of its insignificance and the tendency to heal rapidly and spontaneously. It was noted by Hanschell (1938), however, that a primary lesion, which appeared 5 days after the presumed infecting coitus, was still present 3 weeks later.

\section{Case Report}

A West Indian seaman, aged 23 years, was first seen on November 16,1954, complaining of painful swellings in both groins, which had been present for 2 weeks. He gave a history of two previous attacks of gonorrhoea and had last indulged in sexual intercourse in Durban 6 weeks before attending the clinic. Three weeks later, while at sea, a small penile sore was noticed, but the patient failed to mention it, and only admitted having observed it after the sore had been seen on examination. Painful swellings in both groins were noticed 4 weeks after the last sexual intercourse, but apparently had not been associated in the patient's mind with the small penile ulcer. No treatment had been sought before November 16.

A small circular ulcer with a whitish base was seen on the edge of the prepuce (Figure). The glands in both groins were tender and swollen, adherent to

\footnotetext{
* Received for publication April 27, 1955.
}

one another and to the deeper tissues, but not to the overlying skin. The lymphadenopathy was more marked on the right side. No other clinical signs of disease were discovered. The blood Wassermann test was negative, as was the lymphogranuloma inguinale complement-fixation test. The Frei skin test was positive on November 18.

Treatment was begun on November 16 with sulphathiazole $1 \mathrm{~g}$. every 6 hours, and on November 18 the ulcer on the prepuce had healed, but the inguinal adenitis was unchanged. The patient was last seen on November 22, 1954, when the adenitis was still considerable and painful, and it was thought that hospitalization might be required. The patient missed his next appointment, presumably having sailed with his ship, and there was no opportunity of repeating the lymphogranuloma inguinale complement-fixation test to confirm that the infection was of recent origin.

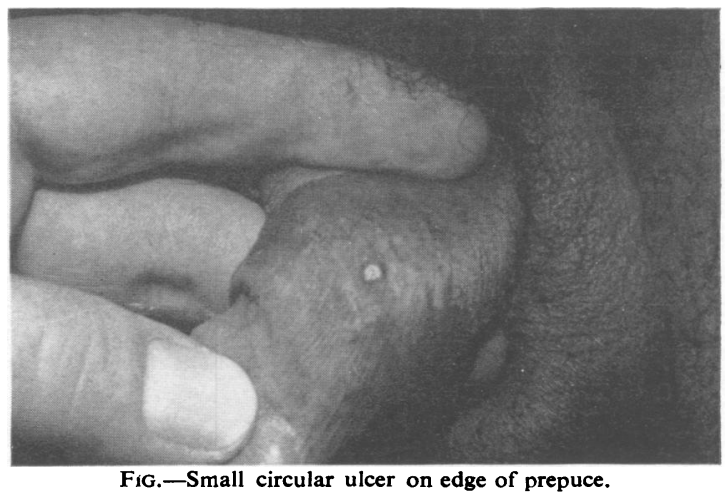

\section{Summary}

A case of lymphogranuloma venereum, in which the herpetiform primary was probably observed, is described and illustrated.

My thanks are due to Dr. E. E. Prebble, Senior Consultant Venereologist, Liverpool Region, for permission to publish this case ; to the Central Photographic Department, Liverpool University, and to the library staff of the Medical Information Division, May and Baker Ltd.

\section{REFERENCES}

Fowler, W, and Walker, B. (1947). Brit. med. J., 1, 182.

Hanschell, H. M. (1938). Trans. roy. Soc. trop. Med. Hyg., 31, 578. Stokes, J. H., Beerman, H., and Ingraham, N. R. (1944). "Modern Clinical Syphilology," 3rd ed. Saunders, Philadelphia. 